\title{
A strawberry, an animal cry and a human subject: Where existential semiotics, biosemiotics and relational metaphysics seem to meet one another
}

\author{
Katarzyna Machtyl ${ }^{1}$
}

\begin{abstract}
The article discusses some semiotic approaches to the relation between nature and culture. Starting with outlining the structuralistic approach to this issue, especially the ideas of Juri Lotman and Algirdas Julien Greimas, the author finds parallels between different views on the relation between the natural world and human beings. First, the juxtaposition of Eero Tarasti's existential semiotics with selected concepts of biosemiotics is discussed. The following part of the paper is dedicated to Bruno Latour's ideas on nature-culture relation, hybrids and mediations. Then the author refers to Lotman's notion of the semiosphere as the common space for all living and inanimate elements. Closing the paper with a return to biosemiotics, the author comes back to Tarasti's ideas and compares these with some ideas in biosemiotics, paying special attention to the concepts of unpredictability, choice and dynamics. The comparison shows that some intuitions, assumptions and theses of these different scholars turn out to be surprisingly convergent. The author believes that the outlined parallels between Tarasti's view, Latour's and Lotman's concepts, and biosemiotics may be promising for further research, inviting detailed study.
\end{abstract}

Keywords: nature; culture; semiotics; existential semiotics; biosemiotics; hybrids; semiosphere; Latour; Tarasti; Lotman

[...] we are no more in Discourse than we are in Nature.

(Latour 1993: 137)

[...] the more distant by its very nature this or that domain is from the sphere of culture, the more effort is applied to introduce it into this sphere.

(Lotman 2009: 134)

Semioticians have usually focused their research efforts on what is connected with the 'sign', i.e. in great simplification, on the 'cultural'. Signs have been understood

1 Department of Cultural Semiotics, Cultural Studies Institute, Adam Mickiewicz University in Poznań, ul. Szamarzewskiego 89A, 60-568 Poznań, Poland; e-mail: machtylk@amu.edu.pl. 
as human, artificial, mediated or code - in short, as everything that is not natural. Only by putting a given phenomenon into signs could it be considered in semiotic categories. As an introduction to this paper I intend to provide a brief discussion of the structuralist approach to this issue, and then present an entirely opposite view by the French philosopher and sociologist Bruno Latour. This juxtaposition serves as an important reference for outlining selected themes within biosemiotics, existential semiotics, and Juri Lotman's approach. The aim is to show some - in my opinion inspiring - parallels between Tarasti's, Latour's and Lotman's concepts in reference to biosemiotics.

\section{Structuralist oppositions. Nature versus culture?}

As we know, structuralist semioticians based their considerations on basic oppositions, in a way drawing on binary logic. Ferdinand de Saussure saw in language a set of binary oppositions, while Claude Lévi-Strauss was concerned with, among others, the opposition of nature and culture, although it should be remembered that in his works he showed a nuanced logic of binary oppositions and also proposed a gradual approach (see, e.g. his culinary triangle or mediations within the structure of myth). Such were also the views of the so-called "early" Lotman, who, to recall his text written together with Boris Uspenskij (Lotman, Uspenskij 1978[1971]), distinguished culture from 'nonculture', and further divided the former into the opposition of 'culture' and 'anti-culture'. In his later works Lotman weakened this version of binarism. Culture and Explosion contains several paragraphs in which Lotman deals with the culture-nature relation, referring, e.g., to physiology. When talking about individual and collective behaviour in the context of abnormality or disturbance he concludes that "psychology and culture are gradually conquering the space of unconscious physiology" (Lotman 2009[1992]: 3). In the chapter dedicated mainly to the mechanism of Ivan the Terrible's cultural behaviour, the author asks "Does physiology shape an "obliging" semiotics that suits its purpose or does semiotics give space to physiology?” (Lotman 2009 [1992]: 83) and continues:

[...] the problem which interested us is located on the border between physiology and semiotics: and in this case the centre of gravity is constantly moving first into one, then into the other sphere. As a semiotic problem, it cannot be artificially isolated from other sociocultural codes, in particular, from the conflict of physiological and cultural aspects. (Lotman 2009[1992]: 112) 
In the context of our discussion one may wish to pay attention to Lotman's significant statement that there is "[...] an essential law: the more distant by its very nature this or that domain is from the sphere of culture, the more effort is applied to introduce it into this sphere. Here it would be possible to highlight the extent of that space which is allotted in culture, even in its highest form - poetry, to the semiotics of wine and love" (Lotman 2009[1992]: 134). The boundaries between nature and culture become blurred and the opposition is less clear than it seems to be.

Staying with structuralism, the neo-structural semiotician Algirdas Julien Greimas should be mentioned as well. Like the authors discussed above, he also, especially in the early phase of his scientific work, based his research on the opposition between nature and culture, and similarly built his semiotic square on binary oppositions. Greimas also draws attention to the connection between the semiotic structuring of the description of the world and its biological structuring (Grzegorczyk 1993: 122). As suggested by Greimas, the moment of the emergence of language ends the development of biologically characterized forms, and thus is the moment of breaking the biological bond between nature and culture. According to him, the semiotic system was created as a result of some kind of "catastrophe" which occurred in the biological system. In effect, language was given a structural mechanism of differentiation into oppositions of otherwise biologically characterized forms, i.e. pregnant forms.

With the emergence of language abrupt development takes place, structured by the semiotic square. In other words, the semiotic square structures nature and culture in leaps and bounds (no longer in an evolutionary manner). However, culture is emotionally and sensually "impregnated" by the evolutionary development of nature so far. In this way, the semiotic square is an abstract matrix for all cultural discourses. Meaning and emotionality thus become the main categories of the semiotic square. It is important for us that Greimas highlights the biological plan, which takes into account emotions and sensuality, and harmoniously combines it with the semiotic plan, which does not resign from language categories. For the sake of clarification it is worth referring to the semiotic dictionary of Greimas and Courtés. In the entry 'Nature' they point out:

Within the framework of structural anthropology, particularly of the LéviStraussian system, the opposition between nature/culture is difficult to define insofar as it is inscribed in different semio-cultural contexts where it designates a relation between what is conceived to refer to culture and what is supposed to belong to nature. Within this perspective nature can never be a kind of first given, original and prior to humans, but a nature which is already informed by culture. It is in this sense that we have taken over this dichotomy by postulating that it 
can articulate the initial elementary investment of the collective semantic universe. (Greimas, Courtés 1982: 211, entry 'Nature’; emphasis added)

Following this way of thinking, Greimas and Courtés clarify the notion of the natural world emphasizing that nature is strongly culture-bound ${ }^{2}$.

Nevertheless, introducing biological themes and emphasizing the issue of nature is still not enough for a topic to be biosemiotic. Biosemiotics is known to be a domain of interdisciplinary research (Kull, Cobley 2017: 5), focused on studying various forms of communication and signification in living systems, and centred around the dialogue between life sciences and humanities. Interestingly, science designed in such a way - and let us remember that its creator is Jakob von Uexküll, who expressed his views in the 1940s - perfectly writes into the contemporary tendencies in humanities. I mean here the division into realists and anti-realists, also called constructivists, which some historians and theoreticians of humanities pursue. This division has replaced the so far most widespread one between naturalists and anti-naturalists, based, to put it briefly, on the assumption that there is a gap between natural sciences and humanities that is impossible to bridge. A radicalized version of such an approach is Bruno Latour's concept that is discussed below. Remaining with biosemiotics, which for the time being has been characterized in a very general way, let us recall that it can also be described interchangeably as a semiotics of nature or a semiotics of life processes which perceives and studies objects throughout the natural and cultural world.

2 "1. We take natural world to mean the seeming by which the universe appears to humans as a set of sensible qualities endowed with a certain organization which occasionally brings it to be designated as the "world of common sense". In relation to the "deep" structure of the universe, which belongs to the physical, chemical, biological, etc. order, the natural world corresponds, as it were, to its "surface structure". On the other hand it is a 'discoursive structure', for it appears within the framework of the subject/object relation: it is the "utterance" constructed by the human subject and decipherable by that subject. Thus we see that the concept of natural world which we propose aims at nothing other than giving a more general semiotic interpretation to the notions of referent or of extra-linguistic context, which appear in strictly linguistic theories.

2. The qualifier natural which we use on purpose to underscore the parallelism between the natural world and natural languages serves to indicate its anteriority in relation to the individual: the latter is inscribed from birth within a signifying world made up of both "nature" and "culture", and is progressively integrated therein through experience. Nature, therefore, is not a neutral referent; it is strongly culture-bound - "If a person grew up all alone would he or she know how to make love?" was sometime ago the theme of a well-known debate in which the responses from the anthropologist and the psychologist were negative - By the very same token, nature is relativized (ethnotaxonomies provide different "world views," for example). This amounts to saying that the natural world is the place for working out a vast semiotics of cultures" (Greimas, Courtés 1982: 374, entry 'World, natural'; emphasis added). 


\section{The common path of existential semiotics and biosemiotics}

In his extensive work Sein und Schein: Explorations in Existential Semiotics (2015), the Finnish semiotician Eero Tarasti refers to biosemiotics. In this book he presents, among other things, his own proposal for the division of signs in relation to Charles S. Peirce's classification. New categories include trans-signs, endo-signs and exo-signs, quasi-signs (as-if-signs) and pheno- and geno-signs. In the short subsection "New types of sign", Tarasti refers to the types of signs he has distinguished in relation to biosemiotics. He recalls the ideas of Jakob von Uexküll and makes an observation, which in my opinion is extremely interesting, that these have some common threads with existential semiotics he himself has proposed. Tarasti (2015: 15) writes: "Biosemiotics does not argue that semiotic and symbolic processes and forms are reducible to something biological, as do some socio-biological theories that say society is ultimately nothing but biology. Rather, it is the other way round: biology and vital processes are shown to be semiosis". In reference to Uexküll, he reminds that biosemiotics "calls the process of sign intruding into the organism and functioning therein endosemiosis. On this basis, we speak of two kinds of signs: endo-signs and exo-signs, signs that are either inside or outside the object" (Tarasti 2015: 15).

According to Tarasti, another point of convergence of biosemiotics and existential semiotics is the assumption of the latter that "neosemiotics never considers only the text but all its conditions, its whole Umwelt, its process of becoming a text, the whole act of enunciation" (Tarasti 2015: 21). At this point, I would like to highlight two issues: firstly, neosemiotics, i.e., implicitly existential semiotics developed by Tarasti, draws attention to the sign or text in its surroundings/environment; secondly, neosemiotics focuses on the process of becoming a text, rather than being a text. This dynamics, which is expressed here, will be important both for biosemiotics, for the "later" Lotman, and also for Latour's concept. I realize that I am juxtaposing here quite distant theoretical perspectives, but the interdisciplinary character of biosemiotics encourages this. In the chapter "Signs around us - umwelt, semiosphere and signscape" Tarasti reviews some approaches to the human subject-environment relations adopted by humanities. He evokes such notions as Greimas' 'surrounding' and 'surrounded' (englobant/englobé), or environment. He inquires about "the relationship of a subject to its environment": "Are our activities predestined by genes and biology? Or guided by education, culture, society or the environment?" (Tarasti 2015: 113). Naturally, he gives various answers, referring to concepts proposed by Hippolyte Taine, Greimas, Uexküll, and others. Importantly for us, he adds that "to our surprise, biosemiotics and existential semiotics agree. They share a 
central claim, namely, that the environment does not dominate the subject but, rather, the other way round: the subject determines the environment" (Tarasti 2015: 117). It is the subject, particularly distinguished in existential semiotics, that influences the environment by his or her various choices: "Yet, since these [surrounding] structures are essentially arbitrary and not dictated by nature, they can be changed, and it is the subject which has the power to change them! On this point - that the subject can make its own possibilities - biosemiotics and existential semiotics agree" (Tarasti 2015: 118). The context and possibilities of the subject itself are concepts combining biosemiotics with existential semiotics. To sum up this part of Tarasti's deliberations, he proposes to capture the various subject-environment relations in the form of taxonomy, where nine logical cases can be distinguished and described with logical symbols, where $S$ stands for the subject and $\mathrm{O}$ for the object in the sense of the environment, similarly to $\mathrm{E}$ :

1. $\mathrm{S} \wedge \mathrm{O}$ "The subject has been conjuncted with the environment; i.e., there is harmony between them. The subject is a part of its environment"

2. $\mathrm{S} \vee \mathrm{E}$ "The subject has been disjuncted from its environment; the subject is separated from its milieu"

3. $\mathrm{S} \rightarrow \mathrm{E}$ "The subject wants, strives for and towards his environment; he tries to become assimilated with it"

4. $\mathrm{S} \leftrightarrow \mathrm{E}$ "The subject wants to be detached from its environment, [...] to distinguish itself from it"

5. $\mathrm{S} \neq \mathrm{E}$ "The subject is indifferent to its surroundings"

6. S "The subject has no environment; it is alone in this world; the environment has been excluded [...] this is like a sender of message without a receiver"

7. E "The mere environment, without any center. For instance, network models are like that. They have no central point, but they are omnipresent". I emphasized here 'network models', because the notion of network will be referred to below when discussing Latour's ideas.

8. $\mathrm{S}=\rightarrow \mathrm{Y}$ "The subject tries to dominate its environment [...], the subject creates a semiosphere suitable for itself"

9. $\mathrm{S} \leftarrow=\mathrm{Y}$ "The environment dominates the subject. The subject is subordinated to the dictatorship of conditions" (Tarasti 2015: 128-130) ${ }^{3}$.

Tarasti (2015: 282) makes also a division into 'semiogerm', 'semiocell' and 'semioactor'; as he puts it, "these notions would cover both biological and cultural,

3 In the context of city space I discuss this taxonomy in Machtyl 2019. 
vegetarian and animal as well as human worlds". This distinction is supposed to be helpful in answering the question: "[...] what kind of dynamic relationship prevails between an organism and its umwelt, isotopy, or semiosphere?" (Tarasti 2015: 282). Juxtaposition of the world of plants, animals and humans seems to be very promising. The last subsection of this paper will return to some of Tarasti's ideas in this field again.

\section{Constructivist integration. Nature $=$ culture}

Bruno Latour is most often described as a sociologist, and then his actor-network theory (ANT) is evoked. However, one can also speak of Latour as a philosopher and then refer to his flat ontology and relational metaphysics. Nevertheless, it is best to take both approaches into account and then it will be possible to get a full picture.

Emphasizing the relations between the actants, Latour avoided the hierarchies and orders of existence established from above; thus, he "flattened", in a way, all the inequalities dividing them. Let us just recall the four central ideas of Latour's metaphysics, and then, against this background, outline the main assumptions of the ANT starting with the notion of hybrids (I have discussed these issues in greater detail in Machtyl 2018). First and foremost, "the world is made up of actors or actants (which I will also call 'objects') [...] all entities are on exactly the same ontological footing" (Harman 2009: 14). Latour's second axiom of metaphysics is the principle of irreduction: "[...] no object is inherently reducible or irreducible to any other" (Harman 2009: 14). Thirdly, "the means of linking one thing with another is translation" - each layer of reality is a mediator, never indifferent, but always adding something when translating from one point to another. Fourthly and finally, "an object is neither a substance nor an essence, but an actor trying to adjust or inflict its forces" (Harman 2009: 15). All these metaphysical axioms, as Graham Harman (2009: 14-15) observes, result from a single, deeper principle absolute concreteness. Every actor is simply what he is, so he is absolutely concrete, and he always gains his reality in a specific time and place.

The currents of ontically oriented contemporary humanities, i.e. objectoriented philosophy and object-oriented ontology, refer to the findings of metaphysical realism and contribute to the current called speculative realism. The latter changes the research perspective, emphasizing ontological categories at the expense of epistemological ones and privileging the notion of the object in relation to the subject. Let us return to Latour and look at his theory of actornetwork. This theory is characterized by translation and the focus on dynamics 
and relativity, so the perspective of philosophical essentialism is rejected here. Two concepts introduced by Latour may prove particularly important for biosemiotic considerations: mediators and intermediaries. In Reassembling the Social (Latour 2005) he attributes the creation of active links to mediators, whereas passive ones to intermediaries; the translations created by mediators are uncertain and not predetermined (the mediator negotiates), while the links between intermediaries are stable - intermediaries do not bring surprises. The ANT is therefore a theory of linkages: the connections, short interactions, depending on time and place, are social - not the world of people and their environment.

As a result, the opposition of nature-culture/society, one of the fundamental oppositions in social sciences and humanities, is rejected. Latour writes metaphorically about zigzag-like transitions from people and objects and specifies that this is not about the ennoblement of an object in the subject-object relationship: there is no relation between nature and culture, between what is material and what is social. It is precisely this distinction that is artificial and erroneous. In the important work We Have Never Been Modern Latour very clearly raises this issue from the perspective of this reflection. In fact, it is becoming the main axis of these considerations, and it is also the basis for answering the question why we have never been modern. In short, modernity has tried at all costs to separate nature and culture by emphasizing the work of purification and ignoring the work of mediation of translation (combining). However, this was an assumption on a declarative level only and has not been implemented; hence, in this sense we have never been modern. Since biosemiotics combines the perspectives of humanities and life sciences, my proposal to include Latour's concept should be clear. What biosemiotics and Latour's concept have in common are not the convergences on the level of language (i.e. of terms) only. "All of culture and all of nature get churned up again every day," Latour (1993: 2) writes already in the opening pages. In his opinion, modernity does not want to notice and admit this, but this is the reality. It is a paradox, Latour (1993: 30) adds, that "[i]f we consider hybrids, we are dealing only with mixtures of nature and culture; if we consider the work of purification, we confront a total separation between nature and culture. It is the relation between these two tasks that I am seeking to understand".

What is more, according to Latour, everything takes place "somewhere in the middle": "here, on the left, are things themselves; there, on the right, is the free society of speaking, thinking subjects, values and of signs. Everything happens in the middle, everything passes between the two, everything happens by way of mediation, translation and networks" (Latour 1993: 37). This approach to the problem is best expressed by the concept of 'Middle Kingdom' to denote this space which has been ignored and neglected by modernity so far: 
How can we go from the world of objects or that of subjects to what I have called quasi-objects or quasi-subjects? How can we move from transcendent/immanent Nature to a nature that is still just as real, but extracted from the scientific laboratory and then transformed into external reality? How can we shift from immanent/transcendent Society toward collectives of humans and nonhumans? [...] How are we to gain access to networks, those beings whose topology is so odd and whose ontology is even more unusual, beings that possess both the capacity to connect and the capacity to divide - that is, the capacity to produce both time and space? How are we to conceptualize the Middle Kingdom? (Latour 1993: 77)

Here the Middle Kingdom is emphasized, and societies and natures (in plural) are its satellites. The Middle Kingdom is, we might add, the result of mediation work, the networks, so far ignored, will be highlighted: "The work of mediation becomes the very centre of the double power, natural and social. The networks come out of hiding. The Middle Kingdom is represented. The third estate, which was nothing, becomes everything" (Latour 1993: 139-140). This abolishes the difference between nature and culture, which are not contradictory but constitute one area established by the work of mediation: "Nature and Society are not two opposite transcendences but one and the same growing out of the work of mediation" (Latour 1993: 87-88) and "we are no more in Discourse than we are in Nature" (Latour 1993: 137). We should add that not only are humans placed in the middle by Latour. In fact, according to him, everything fits in the middle, humans among others - this is what we should say while maintaining his optics. As Graham Harman (2009: 14) claims, Latour's thought "ends the tear-jerking modern rift between the thinking human subject and the unknowable outside world, since for Latour the isolated Kantian human is no more and no less an actor than the windmills, sunflowers, propane tanks, and Thailand", and he goes on to state: "His philosophy unfolds not amidst shifting fortunes of a bland human-world correlate, but in the company of all possible actants: pine trees, dogs, supersonic jets, living and dead kings, strawberries, grandmothers, propositions, and mathematical theorems" (Harman 2009: 16). Hence the strawberry in the title of my article. Latour himself (1993: 5) proposes to consider such entities as moral law, ozone hole, industry, or soul together, not as distinctive entities, but as compatible ones. How is this possible? What connects all these actants? The network: "Is it our fault if the networks are simultaneously real, like nature, narrated, like discourse, and collective, like society?" (Latour 1993: 6). Quasi-objects exist within the network: "Quasi-objects are in between and below the two poles, at the very place around which dualism and dialectics had turned endlessly without being able to come to terms with them" (Latour 1993: 55). They are both social and real. Returning to these hybrids, let us observe that Latour clearly writes that they are created 
through translation and are a kind of mixture of culture and nature, while purification separates the human from the non-human (Latour 1993: 10-11). The problem with the classification of individual actants shows clearly that we are dealing with a network of hybrids rather than with two kingdoms that never meet; even more, Latour observes that hybrids are constantly multiplying ${ }^{4}$.

At the end of the discussion of Latour's concept from the point of view of the issues that concern us here, we once again return to the notion of mediators and intermediaries. The intermediary only transfers, transmits energy between poles, establishes links between nature and society, but does not itself have an ontological status, while the mediator creates both the translation itself and the beings between which he meditates (Latour 1993: 78). "If we simply restore this mediating role to all the agents, exactly the same world composed of exactly the same entities ceases being modern and becomes what it has never ceased to be that is, non-modern" (Latour 1993: 78). A mediator is not loyal, he is an actor who has agency. As Latour (1993: 81) metaphorically put it, "The serfs have become free citizens once more". Citizens of the Middle Kingdom, we should add.

\section{Semiosphere as a common space}

Juri Lotman's late concept of the semiosphere is quite different from those presented in the first subsection of this paper, but it is still structuralist in its nature. I would like to discuss the similarities and differences between Lotman's concept and some of Latour's theses on the nature-culture connection and hybrid natures. Referring mainly to Lotman's texts "Semiotic space" and "On the semiosphere", I would like to pay special attention to the process of broadening the notion of the semiosphere. First of all, it is significant that Lotman founded this term by analogy to V. I. Vernadsky's concept of biosphere:

By analogy with the biosphere (Vernadsky's concept) we could talk of a semiosphere, which we shall define as the semiotic space necessary for the existence and functioning of languages, not the sum total of different languages; in a sense the semiosphere has a prior existence and is in constant interaction with languages. (Lotman 2001: 123)

4 "But where are we to classify the ozone hole story, or global warming or deforestation? Where are we to put these hybrids? Are they human? Human because they are our work. Are they natural? Natural because they are not our doing. Are they local or global? Both. As for the human masses that have been made to multiply as a result of the virtues and vices of medicine and economics, they are no easier to situate. In what world are these multitudes to be housed? Are we in the realm of biology, sociology, natural history, ethics, sociobiology?" (Latour 1993: 50) 
Importantly, and in my opinion also in line with Latour's view (I refer to the socalled Middle Kingdom), Lotman writes that it is not possible to consider systems in an isolated form today. In reality, "they function only by being immersed in a specific semiotic continuum, which is filled with multi-variant semiotic models situated at a range of hierarchical levels" (Lotman 2005: 206). It should be added that according to Vernadsky,

[...] biosphere is a cosmic mechanism, which occupies a specific structural place in planetary unity. Situated on the surface of our planet and including within itself the totality of living things, the biosphere transforms the radiated energy of the sun into the chemical and physical, and is concerned with the transformation of the inert inanimate materials of our planet. (Lotman 2005: 207)

The notion "the totality of living things" should be of a particular interest for us here. Of course, Lotman does not convince the reader here that the semiosphere, like the biosphere, consists of "the totality of living things", it is only an analogy in which the semiotician states that the semiosphere consists of a whole set of texts and languages, but the very concept of a 'whole' and not just a 'sum' probably suggests a convergence with Latour's concept. What is especially important for me is that in his text "On the semiosphere" Lotman developed this concept highlighting the biological analogies, i.e. using terms such as a membrane or a living cell. The notion of boundary (discussed in the text under the same title) is helpful in explicating the notion of non-semiotic and extra-semiotic spaces with which the semiosphere has a permanent contact:

The notion of boundary is an ambivalent one: it both separates and unites. It is always the boundary of something and so belongs to both frontier cultures, to both contiguous semiospheres. The boundary is bilingual and polylingual. The boundary is a mechanism for translating texts of an alien semiotics into 'our' language, it is the place where what is 'external' is transformed into what is 'internal', it is a filtering membrane which so transforms foreign texts that they become part of the semiosphere's internal semiotics while still retaining their own characteristics. (Lotman 2001: 136-137)

Thus the boundary is something in common, as it not only divides, but also unites. It is the boundary where the above-mentioned invasions and intrusions come about, which, as it has been pointed out, energize and enrich culture instead of destroying it. External texts are filtered through the boundary and absorbed by the semiosphere through the translation into a known language. Thus a pool of texts and meanings of a given culture becomes richer, which is definitely a good thing: 
In the frontier areas semiotic processes are intensified because here there are constant invasions from outside. [...] The extreme edge of the semiosphere is a place of incessant dialogue. [...] In reality no semiosphere is immersed in an amorphous, "wild" space, but is in contact with other semiospheres which have their own organization (though from the point of view of the former they may seem unorganized) there is a constant exchange, a search for a common language [...]. (Lotman 2001: 141-142; see also Lotman 2005: 210)

The boundary is a place of intensification of semiotic processes, and the semiosphere itself is abundantly crossed by various boundaries, so we can talk about its heterogeneity.

An important observation for us is that, in the light of Lotman's concept, the opposition between culture and nature is still strong, but the semiosphere is open to non-human and non-anthropogenic elements: "This is the sense of semiosphere in the contemporary world, steadily expanding into space over the centuries, it has now taken on a global character, and includes within itself the call signs of satellites, the verse of poets and the cry of animals. The interdependence of these elements of the semiosphere is not metaphorical, but a reality" (Lotman 2005: 219). What we are dealing with here is a quite surprising statement which does not seem to have been formulated as directly by Lotman until then. The semiosphere does not only include people, messages, languages and texts, i.e. what is inherent in human communication and signification processes, but also signals from sputniks and animal cries. Is it not a certain visible parallel to Latour's thoughts? Strawberries, mathematical theorems, ozone holes and humans form a single world of hybrids and quasi-objects in Latour's view; they inhabit the Middle Kingdom. Is Lotman's semiosphere not its equivalent? After all, the semiotician continues to ask: "[...] is the whole universe not a form of communication, falling within an ever more general semiosphere? Is it not destined for a universal reading? It is doubtful whether we were able to find an answer to this question" (Lotman 2005: 220). Latour seems to have answered this question very clearly, although not from a semiotic perspective. I think that some of Lotman's intuitions coincide with those of Latour. Of course, the author of Culture and Explosion pronounced them much more timidly than the Frenchman, but a certain thread connecting the two approaches can be pointed out. As new actants, e.g. hybrids, appear and the physical environment has been subjected to change - the semiosphere needs to be broadened. 


\section{Biosemiotics once again}

After outlining the concepts that interest me in this context, let us return to biosemiotics designed, as it has already been said, as "the semiotics of life". Franco Giorgi (2017: 11), outlining the idea of biosemiotics by Don Favareau, recalled the latter's statement that natural sciences focus on material entities while symbol studies study immaterial relations. Giorgi continues: "In Don [Favareau]'s view, this discrepancy can only be solved by rediscovering the role that signinterpretations play in the relationships that living creatures, as driven by their internal casual interactions, entertain with the unpredictable demands of the external environment" (Giorgi 2017: 11). Thus, we have internal motives of living creatures confronted with unpredictable demands of the external environment. At this point we can recall the nine types of relations into which the subject enters with its external environment, listed by Tarasti, but also the work of mediation in Latour's perspective. I would like to emphasize the term 'unpredictable', which also characterizes Favareau's concept, and which, in my opinion, excellently corresponds with Lotman's notion of explosion and unpredictability ${ }^{5}$. As Giorgi (2017: 12) observes, Favareau suggested considering the issue both diachronically and synchronically; hence he indicated that signs do not only influence new semantic typologies, but also act "as flexible linkers, capable of modifying each other's referential functions under different types of combinations". Is Latour's mediator not working in a similar way? After all, it is a combination of subjectdependent experience and subject-independent reality in the perspective of the third element, which is the context.

5 Lotman distinguishes two types of development of the system of culture: a gradual one and one in the way of explosion which is understood as: "[...] the place where a sharp increase in the informativity of the entire system takes place. The developmental curve jumps, here, to a completely new, unpredictable and much more complex path. The dominant element, which appears as a result of the explosion and which determines future movement, can come from any element of the system or may even be an element of another system, randomly pulled by the explosion into the web of possibilities of future movement. However, in the following stage, this element will already have created a predictable chain of events" (Lotman 2009: 14). And further: "The moment in which the explosion is exhausted represents the turning point of the process. In the sphere of history this is not only the originating moment of future development but also the place of self-knowledge: the inclusion of those mechanisms of history which must themselves explain what has occurred. Further development seems to take us back to the original point of explosion, which already exists in our consciousness. What has occurred takes on a new form of existence, and is reflected in the ideas of the observer. In this way a radically transformative event occurs: that which occurred, as we have seen, by chance, now appears to be the only possibility. The element of unpredictability is substituted in the mind of the observer by an element of regularity" (Lotman 2009: 15). See also Lotman 2013. 
Interestingly, Giorgi lists several biological functions that can be considered as semiotic in this case, i.e. action, choice, recognition and communication. He also indicates that the future can be predicted in two ways, a scientific one, where, on the basis of research and experiments, we can expect certain events with a high probability; and by anticipation of the future as a sign, where a whole bundle of unpredictable possibilities emerges. This is an expression of "how the transition from a scientifically predictable world to a semiotically unexpected world opens a horizon of creativity and combines the novelty of the unprecedented with the usefulness of the nature's availability" (Giorgi 2017: 13). Favareau's focus on the future which is unpredictable from a semiotic perspective has also been noticed by another of his interpreters, Kalevi Kull. In "What is the possibility?" Kull (2017: 16) observes that possibilities do not concern the dead and those who do not interpret, and he calls this phenomenon "existence of choice or [...] existence of semiosis". While characterizing the possibilities, he indicates their certain indispensable features, i.e., firstly, an option - so "an option is a behaviour that can be chosen", then, the subjective present or simultaneity of options: "Semiosis takes place only in the Now" (Kull 2017: 18). Also, the key role is played by the subject, since if "it does not include choice, it cannot make meaning" (Kull 2017: 19). The moment of choice, the moment of indecision is necessary for the existence of possibility. Freedom of "the Now" means confusion and opens up a field of possibilities.

It is worth mentioning that Kull also refers to Peirce's semiotics, including his typology of signs and the construction of a sign as such. Let us recall that, according to Peirce, the sign is triadic, as it consists of an object, a representamen and an interpretant. Kull interprets this as a simultaneous occurrence of these elements, not their succession. He considers this to be in line with the notion of possibility as appearing simultaneously. Concluding his reflections, Kull (2017: 23) writes that "every organism is a hybrid of semiosis and machine". I think that the analogy with Latour is sufficiently clear here. Let me close the above considerations with Tarasti's statements on biosemiotics. First of all, a certain link between Tarasti's existential semiotics and biosemiotics is the unpredictability mentioned above: "[...] in existential semiotics there is no return - what happens next is always unknown and unpredictable" (Tarasti 2015: 15). Following Thure von Uexküll, he also observes that the doctrine of Jakob von Uexküll "is particularly compatible with Peirce's semiotics", which was also indicated by Kull. Tarasti (2015: 15) immediately adds, which is crucial to us, "but nothing prevents us from using it in other conceptual frameworks as well". "For instance, the notion of umwelt is doubtless akin to Greimas's 'isotopes' and Lotman's 'semiosphere"' (Tarasti 2015: 120; see also Tarasti 2015: 281). 
The relations between nature and culture have long belonged to the fundamental issues of humanities, having been considered in various ways and from very different theoretical perspectives: the thoughts of Latour and Lotman, for example, may seem nigh impossible to compare. However, as I have tried to show, many issues are connected by the concepts discussed above, and not only on a purely conceptual level. Some intuitions, assumptions and theses turn out to be surprisingly convergent. As biosemiotics is based on interdisciplinarity, so I feel justified in proposing a juxtaposition of some selected theories, which may bring along a new perspective on fundamental biosemiotics issues. Parallels between Tarasti's view, Latour's and Lotman's concepts, and the biosemiotics perspective which I have tried to outline are surprising and inspiring at the same time. Besides, as it seems, the modern world, in which - as Latour wrote - hybrids multiply, requires revision of our views on the relations between nature and culture. It turns out that the human world is at the same time a world in which a human and a non-human subject, a strawberry and a cry of animals have their place. Even more so, also hybrids have their place here, and the Middle Kingdom finally has obtained its voice.

\section{References}

Giorgi, Franco 2017. The introduction of the relevant next. In: Kull, Kalevi; Cobley, Paul (eds.), Biosemiotics in the Community: Essays in Honour of Donald Favareau. Tartu: University of Tartu Press, 11-14.

Greimas, Algirdas Julien; Courtés, Joseph 1982. Semiotics and Language: An Analytical Dictionary. (Crist, Larry; Patte, Daniel; Lee, James; McMahon, Edward; Phillips, Gary; Rengstorf, Michael, trans.) Bloomington: Indiana University Press.

Grzegorczyk, Anna 1993. Posłowie [Afterword]. In: Greimas, Algirdas Julien, O niedoskonałości [On Imperfection]. (Grzegorczyk, Anna, trans.) Poznań: Adam Mickiewicz University Press, $115-146$.

Harman, Graham 2009. Prince of Networks: Bruno Latour and Metaphysics. Melbourne: re.press. Kull, Kalevi 2017. What is the possibility? In: Kull, Kalevi; Cobley, Paul (eds.), Biosemiotics in the Community: Essays in Honour of Donald Favareau. Tartu: University of Tartu Press, 15-25.

Kull, Kalevi; Cobley, Paul 2017. Signatum. In: Kull, Kalevi; Cobley, Paul (eds.), Biosemiotics in the Community: Essays in Honour of Donald Favareau. Tartu: University of Tartu Press, 5-6.

Latour, Bruno 1993. We Have Never Been Modern. (Porter, Catherine, trans.) Cambridge: Harvard University Press.

- 2005. Reassembling the Social: An Introduction to Actor-Network-Theory. New York: Oxford University Press. 
Lotman, Juri M. 2001[1990]. Universe of the Mind: A Semiotic Theory of Culture. (Shukman, Ann, trans.) London: I. B. Tauris Publishers.

- 2005[1984]. On the semiosphere. (Clark, Wilma, trans.) Sign Systems Studies 33(1): 205229.

- 2009[1992].Culture and Explosion. (Clark, Wilma, trans.; Grishakova, Marina, ed.) Berlin: Mouton de Gruyter.

- 2013. The Unpredictable Workings of Culture. (Baer, Brian James, trans.; Pilchikov, Igor; Salupere, Silvi, eds.) Tallinn: TLU Press.

Lotman, Juri M.; Uspenskij, Boris A. 1978[1971]. On the semiotic mechanism of culture. (Mihaychuk, George, trans.) New Literary History 9(2): 211-232.

Machtyl, Katarzyna 2018. In the semiotic network: Signs, subjects, objects and all in between.

In: Martinelli, Dario (ed.), CROSS-INTER-MULTI-TRANS-. Proceedings of the 13th World Congress of the International Association for Semiotic Studies (IASS/AIS). Kaunas: Publishing House "Technologija", 415-422.

- 2019. The surrounding and the surrounded. Dynamic city-subject relation in the light of existential semiotics. ПРАЕHMA: Journal of Visual Semiotics 1(19): 106-119.

Tarasti, Eero 2015. Sein und Schein: Explorations in Existential Semiotics. Berlin: Mouton de Gruyter.

\section{Клубника, крик животного и человек: где экзистенциальная семиотика, биосемиотика и реляционная метафизика, видимо, встречаются друг с другом}

В статье обсуждаются некоторые семиотические подходы к взаимосвязи между природой и культурой. Начав с изложения структуралистского подхода к этому вопросу, особенно идей Юрия Лотмана и Альгирдаса Жюльена Греймаса, автор находит параллели между различными взглядами на отношение между природным миром и человеком. Во-первых, обсуждается взаимосвязь экзистенциальной семиотики Эеро Тарасти с некоторыми теориями биосемиотики. Следующая часть статьи посвящена идеям Бруно Латура о взаимосвязи природа - культура, гибридах и медиумах. Затем автор ссылается на представление Лотмана о семиосфере как общем пространстве для всех живых и неодушевленных элементов. Заканчивается статья возвращением к концепциям Тарасти, которые сравниваются с некоторыми идеями биосемиотики, при этом особое внимание уделяется понятиям непредсказуемости, выбора и динамики. Сравнение показывает, что некоторые интуиции, предположения и положения столь разных ученых оказываются на удивление похожими. Автор полагает, что обозначенные параллели между точкой зрения Тарасти, концепциями Латура и Лотмана и биосемиотики могут быть перспективны для дальнейших исследований. 


\section{Maasikas, loomakarje ja inimsubjekt - kus kohtuvad eksistentsiaalsemiootika, biosemiootika ja relatsiooniline metafüüsika}

Artiklis käsitletakse mõningaid semiootilisi lähenemisi looduse ja kultuuri vahelisele suhtele. Alustades sellest, et visandatakse strukturalistlik lähenemine sellele teemale, eriti Juri Lotmani ja Algirdas Julien Greimasi ideede osas, leiab autor paralleele erinevate vaatenurkade vahel loodusmaailma ja inimeste suhtele. Esimesena vaadeldakse Eero Tarasti eksistentisiaalsemiootikat kõrvutatuna valitud biosemiootika mõistetega. Artikli järgmine osa on pühendatud Bruno Latouri ideedele looduse ja kultuuri suhete, hübriidide ja vahenduste kohta. Seejärel viitab autor Lotmani semiosfääri mõistele kui kõigi elusate ja elutute elementide ühisruumile. Artikkel lõpeb tagasipöördumisega biosemiootika juurde, kui autor naaseb Tarasti mõistete juurde ja võrdleb neid mõnede biosemiootika ideedega, pöörates erilist tähelepanu ennustamatuse, valiku ja dünaamika mõistetele. Kõrvutusest ilmneb, et nende erinevate teadlaste mõned äratundmised, oletused ja teesid osutuvad üllatavalt konvergentseteks. Autori arvates võivad visandatud paralleelid Tarasti vaatenurga, Latouri ja Lotmani mõistete ning biosemiootika vahel olla paljutõotavad, pidades silmas edasisi uurimusi, ning kutsuvad üles üksikasjalisematele vaatlustele. 